\title{
Effect of Composts Combined with Chemical N Fertilizer on Nitrogen Uptake by Italian Ryegrass and N Transformation in Soil
}

\author{
Nguyen Thanh Binh ${ }^{1,2 *}$, Hoang Thi Quynh' ${ }^{3}$ Kazuto Shima ${ }^{1}$ \\ ${ }^{1}$ Department of Environmental Ecology, Graduate School of Environmental and Life Science, Okayama \\ University, Okayama, Japan \\ ${ }^{2}$ Department of Soil Agro-Chemistry, Faculty of Agronomy, Nonglam University, Ho Chi Minh City, Vietnam \\ ${ }^{3}$ Vietnam Institute of Meteorology, Hydrology and Climate Change (IMHEN), Hanoi, Vietnam \\ Email: binhnguyen0804@gmail.com
}

Received 26 February 2015; accepted 7 April 2015; published 8 April 2015

Copyright (C) 2015 by authors and Scientific Research Publishing Inc.

This work is licensed under the Creative Commons Attribution International License (CC BY).

http://creativecommons.org/licenses/by/4.0/

(c) (i) Open Access

\begin{abstract}
Combining compost with sufficient chemical $\mathbf{N}$ fertilizer (CF) in agricultural lands is a popular practice to reduce the amount of inorganic nitrogen and accumulation of non-nutrient constituents in soils. A pot culture experiment was conducted to study the effects of $130 \mathbf{~ m g ~} \mathbf{N}$ of either solids waste compost (Scomp) or biosolids waste compost (Bcomp) complemented with $130 \mathrm{mg}$ (CF, 1N) and 260 mg.N·pot ${ }^{-1}(\mathrm{CF}, 2 \mathrm{~N})$ as ${ }^{15} \mathrm{~N}$ labeled $\left(\mathrm{NH}_{4}\right)_{2} \mathrm{SO}_{4}(13.172$ atom \%) on growth and $\mathrm{N}$ uptake by Italian ryegrass. A separate soil incubation without plants was set up by only blends of Scomp and CF. The results from pot culture experiment show that total plant biomass and $\mathrm{N}$ uptake from Bcomp were significantly higher than Scomp alone. Scomp combined with $\mathrm{CF}$ improved yield and $\mathrm{N}$ uptake over those of Scomp alone. For Scomp + 1N treatment, plant nitrogen uptake derived from compost and CF accounted for $29 \%$ and $56 \%$ of added $N$ from Scomp and CF, respectively. The incubation study indicates that $16.08-29.62 \mathrm{mg} \cdot \mathrm{N} \cdot \mathrm{kg}^{-1} \cdot \mathrm{soil} \cdot \mathrm{day}^{-1}$ from inorganic- $\mathrm{N}$ were immobilized into organic pools, while only $0.40-0.66 \mathrm{mg} \cdot \mathrm{N} \cdot \mathrm{kg}^{-1} \cdot \mathrm{soil} \cdot \mathrm{day}^{-1}$ from organic- $\mathrm{N}$ were mineralized to inorganic pools. Because a part of additional $\mathbf{N}$ could be tied up in organic form, combining solids compost with chemical $\mathbf{N}$ fertilizer therefore need to consider the effective use of compost- $\mathbf{N}$.
\end{abstract}

\section{Keywords}

Solids, Biosolids Compost, ${ }^{15} \mathrm{~N}$ Nitrogen Uptake, Mineralization, Immobilization

\footnotetext{
${ }^{*}$ Corresponding author.

How to cite this paper: Binh, N.T., Quynh, H.T. and Shima, K. (2015) Effect of Composts Combined with Chemical N Fertilizer on Nitrogen Uptake by Italian Ryegrass and N Transformation in Soil. Journal of Agricultural Chemistry and Environment, 4, 37-47. http://dx.doi.org/10.4236/jacen.2015.42004
} 


\section{Introduction}

Composting of organic wastes has long been considered an attractive waste management option for effective reduction of waste volume. Municipal solids waste and biosolids/sewage sludge compost have been numerously reported to increase crop yields [1] [2], and improve soil properties [3] [4]. In Vietnam, however, land application has not been widely used for industrial wastes due to poor quality composts [5], the complexity of raw materials, or inefficient uses of them.

The nitrogen mineralization from some composts takes place slowly due to high C:N ratios of amendments. Combining compost and inorganic fertilizer has generally been more effective than separate application of either material alone. Adding nitrogen also aims to accelerate the decrease in the C:N ratios of composts. Asghar [6] observed that compost combining with $50 \%$ recommended inorganic $\mathrm{N}$ fertilizer gave almost same results as the $100 \% \mathrm{~N}$ fertilizer alone. Esawy et al. [7] indicated that the average cumulative cucumber yield was higher with $75 \%$ mineral $\mathrm{N}+25 \%$ organic $\mathrm{N}$ over those of fertilizer alone.

The studies reported above provide very little information on the partitioning of applied $\mathrm{N}$ as well as availability of compost-N. The introduction of isotopic pool dilution approach and tracer technique has proven very advantageous in determining the transformation and fate of fertilizer $\mathrm{N}$ [8]-[10]. In this report, ${ }^{15} \mathrm{~N}$ dilution method was used to distinguish nitrogen derived from compost and from chemical fertilizer as well as to measure nitrogen transformations between organic and inorganic sources in compost amended soil.

Therefore, the objectives of this study were to 1 ) determine if the combination could change the $\mathrm{N}$ mineralization of composts amended soil; 2) quantify and distinguish the fertilizer ${ }^{15} \mathrm{~N}$ uptake by ryegrass; and 3) measure the soil gross mineralization-immobilization rates.

\section{Materials and Methods}

\subsection{Pot Culture Experiment}

The pot culture experiment with Italian ryegrass (Lolium multiflorum L.) was conducted from September to October, 2011 in Okayama, Japan under room condition where air temperature was maintained at $35^{\circ} \mathrm{C} / 25^{\circ} \mathrm{C}$ (day/night). The sandy soil was air-dried and passed through a $2 \mathrm{~mm}$ sieve. The soil had pH 7.1 (in 1:2.5 soil: water suspension), total carbon of $0.2 \mathrm{~g} \cdot \mathrm{kg}^{-1}$, total nitrogen of $0.051 \mathrm{~g} \cdot \mathrm{kg}^{-1}$, a C:N ratio 3.9. Biosolids compost (Bcomp) was co-processed for 50 days using a blower system with aerated windrows method mixing sewage sludge (raw material), brewery waste (sub-raw material) and wood chips as bulking agent. Bcomp was collected from Chugoku Yuki composting facility in Japan. Municipal solids waste compost (Scomp) was previously obtained from Thuy Phuong composting plant in Vietnam, and then carried to Japan for investigation. The chemical properties of two composts are summarized in Table 1.

The preliminary experiment was conducted from April to August, 2011 to evaluate above biosolids compost quality through maturity index and biomass yield of Italian ryegrass [11]. The result showed that the total biomass yield significantly increased with increasing biosolids compost-N rates up to $150 \mathrm{~kg} \cdot \mathrm{N} \cdot \mathrm{ha} \mathrm{p}^{-1}$. These rates of compost were used as reference data for the current study. For treatments with compost, a sample of $650 \mathrm{~g}$ soil (dry weight basis) was hand mixed well with either Scomp or Bcomp equivalent to $130 \mathrm{mg} \cdot \mathrm{N} \cdot \mathrm{pot}^{-1}$, and transferred into plastic Neubauer' pots $100 \mathrm{~cm}^{2}(11.28 \mathrm{~cm}$ in diameter $\times 6.6 \mathrm{~cm}$ in depth). For treatments with CF, the same amount of soil was added with two rates $\left(130 \mathrm{mg} \cdot \mathrm{N} \cdot \mathrm{pot}^{-1}, 1 \mathrm{~N}\right.$ and $\left.260 \mathrm{mg} \cdot \mathrm{N} \cdot \mathrm{pot}^{-1}, 2 \mathrm{~N}\right)$ as ${ }^{15} \mathrm{~N}$-labeled ammonium sulfate (13.172 atom\%) in solution. All treatments except control received $100 \mathrm{mg} \cdot \mathrm{P} \cdot \mathrm{pot}^{-1}$ as $\mathrm{Ca}_{3}\left(\mathrm{PO}_{4}\right)_{2}$. The details of different treatments are given in Table 2.

Ryegrass was sown at density of 20 seeds $\cdot$ pot $^{-1}$, which was equivalent to 2000 seeds $\cdot \mathrm{m}^{-2}$, over a $0.5 \mathrm{~cm}$ soil surface layer to facilitate seed germination. After sowing 45 days, all plant parts (including shoot and root) were harvested separately, dried at $100^{\circ} \mathrm{C}$ for 26 hours. Plant parts $\mathrm{N}$ contents were determined by dry combustion method using CN corder (TM-700). Shoot and root dry weight were multiplied by the respective $\mathrm{N}$ content, and then summarized in total plant $\mathrm{N}$ uptake. All treatments were arranged in a randomized complete block design with three replications.

\subsection{Incubation Study}

The incubation study was conducted to determine gross total $\mathrm{N}$ mineralization and gross total $\mathrm{N}$ immobilization rates after combining Scomp with CF. Soil, compost and ${ }^{15} \mathrm{~N}$-labeled $\left(\mathrm{NH}_{4}\right)_{2} \mathrm{SO}_{4}(13.172$ atom\%) were prepared 
Table 1. Chemical constituents of solids compost and biosolids compost.

\begin{tabular}{|c|c|c|}
\hline Constituent & Scomp & Bcomp \\
\hline $\mathrm{pH}$ & 8.7 & 7.2 \\
\hline Total carbon $\left(\mathrm{g} \cdot \mathrm{kg}^{-1}\right)$ & 123.0 & 248.1 \\
\hline Total nitrogen $\left(\mathrm{g} \cdot \mathrm{kg}^{-1}\right)$ & 11.4 & 37.7 \\
\hline $\mathrm{C} / \mathrm{N}$ ratio & 10.8 & 6.6 \\
\hline \multicolumn{3}{|l|}{ Inorganic $\mathrm{N}$} \\
\hline $\mathrm{NH}_{4}-\mathrm{N}\left(\mathrm{g} \cdot \mathrm{kg}^{-1}\right)$ & 0.97 & 11.65 \\
\hline $\mathrm{NO}_{3}-\mathrm{N}\left(\mathrm{g} \cdot \mathrm{kg}^{-1}\right)$ & 0.03 & 0.79 \\
\hline Total phosphorus $\left(\mathrm{g} \cdot \mathrm{kg}^{-1}\right)$ & - & 53.2 \\
\hline \multicolumn{3}{|c|}{ Exchangeable cations $\left(\mathrm{cmol} \cdot \mathrm{kg}^{-1}\right)$} \\
\hline $\mathrm{K}^{+}$ & 15.6 & 12.6 \\
\hline $\mathrm{Na}^{+}$ & 10.0 & 6.3 \\
\hline $\mathrm{Ca}^{2+}$ & 34.0 & 16.6 \\
\hline $\mathrm{Mg}^{2+}$ & 5.6 & 33.0 \\
\hline \multicolumn{3}{|l|}{ Total heavy metal $\left(\mathrm{mg} \cdot \mathrm{kg}^{-1}\right)$} \\
\hline $\mathrm{Zn}$ & $202.1(5.3)^{\dagger}$ & $205.4(0.3)$ \\
\hline $\mathrm{Cu}$ & $318.6(3.5)$ & $137.7(0.5)$ \\
\hline $\mathrm{Cd}$ & 8.2 & 8.0 \\
\hline $\mathrm{Ni}$ & 99.3 & 18.3 \\
\hline
\end{tabular}

${ }^{\dagger}$ Numbers in parentheses are available heavy metals.

Table 2. Treatment combinations and weight of ingredients.

\begin{tabular}{cccccc}
\hline Treatment & Soil & Scomp & Bcomp & $\left(\mathrm{NH}_{4}\right)_{2} \mathrm{SO}_{4}$ & Total N applied \\
\hline Control (0N) & 33.15 & - & - & - & 0 \\
CF (1N) & 33.15 & - & - & 130 & 130 \\
CF (2N) & 33.15 & - & - & 260 & 130 \\
Scomp & 33.15 & 130 & - & - & 260 \\
Scomp + 1N & 33.15 & 130 & - & 260 & 390 \\
Scomp + 2N & 33.15 & 130 & - & - & 130 \\
Bcomp & 33.15 & - & 130 & 130 & 260 \\
Bcomp + 1N & 33.15 & - & 130 & 260 & 390 \\
Bcomp + 2N & 33.15 & - & 130 & & 260 \\
\hline
\end{tabular}

as same method with above pot culture experiment without plants. The pots were additional covered with aluminum foil perforated five small needle holes to ensure gas exchange and minimize water loss. Then the amended soil samples were incubated in dark at $25^{\circ} \mathrm{C}$ and $35^{\circ} \mathrm{C}$ for 10 days. During the incubation time, soil was weighed daily and adjusted with distilled water to $60 \%$ holding capacity. The sampling was destructed at 2, 5, and 10 days by removing pots in triplicate for each treatment. To ensure the homogeneity without changing inorganic nitrogen contents, soil was dried at low temperature in vacuum chambers before sampling. 
Inorganic $\mathrm{N}$ was completely extracted from the soil samples by $2 \mathrm{M} \mathrm{KCl} \mathrm{(w:} \mathrm{v}=1: 5)$ after shaking for 1 hour. The filtered solution was immediately analyzed for $\mathrm{NH}_{4}-\mathrm{N}$ and $\mathrm{NO}_{3}-\mathrm{N}$ using indophenols-blue and Vanadium (III) chloride reduction method [12], respectively. After extraction, the residual soil was washed in alcohol $60 \%$, dried and ground to a very fine powder before analyzing ${ }^{15} \mathrm{~N}$ immobilized in organic soil by the CN-cordercoupled with isotope Quadrupole mass spectrometry (Ulvac).

\subsection{Calculations and Statistical Analysis}

Total plant $\mathrm{N}$ uptake derived from chemical $\mathrm{N}$ fertilizer $\left(\mathrm{N}_{\mathrm{dfCF}}\right)$ was calculated directly using the formula of Hauck and Bremner [13]:

$$
\mathrm{N}_{\mathrm{dfCF}}=T N U(c-b) /(a-b)
$$

where, $T N U$ is total $\mathrm{N}$ uptake in plant part; $a, b$, and $c$ are the atom $\%{ }^{15} \mathrm{~N}$-labeled $\left(\mathrm{NH}_{4}\right)_{2} \mathrm{SO}_{4}(13.172 \%)$, plant part or soil receiving no ${ }^{15} \mathrm{~N}$, and plant part receiving ${ }^{15} \mathrm{~N}$, respectively. The denominator $b$ value in the formula (1) was assumed to be equal to natural abundance (0.366\%). Total plant $\mathrm{N}$ uptake derived from compost $\left(\mathrm{D}_{\mathrm{dfComp}}\right)$, from soil $\left(\mathrm{N}_{\mathrm{dfs}}\right)$ and nitrogen uptake efficiency (NUE) were calculated using difference method of Westerman and Kurtz [14].

The gross $\mathrm{N}$ mineralization rate was simply calculated using the following derivation of isotope dilution:

$$
\mathrm{G}_{m i}\left(\mathrm{mg} \mathrm{N} \mathrm{kg}{ }^{-1} \text { soil }\right)=\frac{\Delta{ }^{15} \mathrm{~N}_{\text {Org }}+\left(\Delta \mathrm{N}_{\text {Inorg }} \times{ }^{15} \mathrm{~N}_{\text {Inorg( }(0)} \text { atom \% }\right)}{{ }^{15} \mathrm{~N}_{\text {Inorg }(0)} \text { atom } \%-{ }^{15} \mathrm{~N}_{\text {Org( }(0)} \text { atom \% }}
$$

where, ${ }^{15} \mathrm{~N}_{\text {Org(0) }}$ and ${ }^{15} \mathrm{~N}_{\text {Inorg(0) }}$ are ${ }^{15} \mathrm{~N}$ atom \% in organic and inorganic pools, respectively, on day $0 . \Delta{ }^{15} \mathrm{~N}_{\text {Org }}$ is difference of ${ }^{15} \mathrm{~N}$ content $\left(\mathrm{mg} \cdot \mathrm{N} \cdot \mathrm{kg}^{-1}\right)$ in organic pools between day t and day $0 . \Delta \mathrm{N}_{\text {Inorg }}$ is the difference $\left(\mathrm{mg} \cdot \mathrm{N} \cdot \mathrm{kg}^{-1}\right)$ of total inorganic nitrogen $\left(\mathrm{NH}_{4}+\mathrm{NO}_{3}\right)$ between day $\mathrm{t}$ and day 0 . For isotopic signal data from mass spectrometry, ${ }^{15} \mathrm{~N}$ atom \% in organic soil was calculated from following formula:

$$
{ }^{15} \mathrm{~N}_{\text {Org }} \text { atom } \%=100 /\left[1+2 \times\left({ }^{28} N_{2} /{ }^{29} N_{2}\right)\right]
$$

To obtain $\mathrm{G}_{\text {mi }}$ of each interval, ${ }^{15} \mathrm{~N}_{\text {Inorg(t) }}$ was calculated indirectly by subtracting ${ }^{15} \mathrm{~N}_{\text {Org(t) }}$ on day t from total initial known ${ }^{15} \mathrm{~N}_{\text {[Org+Inorg](0) }}$ on day 0 . Therefore, in this model the loss of $\mathrm{N}$ as unaccounted proportions were assumed to be negligible.

Gross N immobilization rate $\left(\mathrm{G}_{i m}\right)$ was calculated following Murphy et al. [10]:

$$
\mathrm{G}_{i m}\left(\mathrm{mg} \cdot \mathrm{kg}^{-1} \text { soil }\right)=\mathrm{G}_{m i}-\mathrm{N}_{m i}
$$

where, $\mathrm{N}_{m i}$ is net mineralization rate calculated by difference of total inorganic nitrogen between day $t$ and 0 .

Means of values were compared with those of others by Fisher's protected least significant difference (LSD) after ANOVA test, using the EXCEL ${ }^{\circledR}$ macro add-ins DSAASTAT Version 1.512 [15].

\section{Results}

\subsection{Pot Culture Experiment}

\section{(1) Growth}

Total dry weight (sum of shoot and root) significantly increased $(P<0.01)$ with CF and/or compost additions compared to control treatment, with the exception of Scomp alone (Figure 1). From 63\% to 95\% of the total dry weight was contributed by shoot biomass (data not shown), indicating that plant growth was greatly affected by variability of nitrogen sources from different treatments. The results show that either Scomp or Bcomp combined with two rates of CF $(1 \mathrm{~N}$ and $2 \mathrm{~N})$ had no effect on yield other than that produced by CF alone. Incremental yield was observed by Scomp $+1 \mathrm{~N}$ compared to Scomp alone. Total dry weight by CF (1N) was not different from CF $(2 \mathrm{~N})$, while total dry weight by Bcomp was significantly higher $(P<0.01)$ than Scomp (Figure 1$)$.

(2) Total Plant N Uptake and Partitioning of Applied Nitrogen

Table 3 shows the partitioning of $\mathrm{N}_{\mathrm{dfComp}}, \mathrm{N}_{\mathrm{dfCF}}$, and $\mathrm{N}_{\mathrm{dfs}}$ as influenced by different fertilizer treatments. Thus, $\mathrm{N}_{\mathrm{dfComp}}$ indicates more clearly difference between compost alone and blend treatments. $\mathrm{N}_{\mathrm{dfC} o m p}$ was all significantly decreased $(P<0.01)$ with two additional $\mathrm{N}$ rates from $\mathrm{CF}$ compared to compost alone, with the exception 


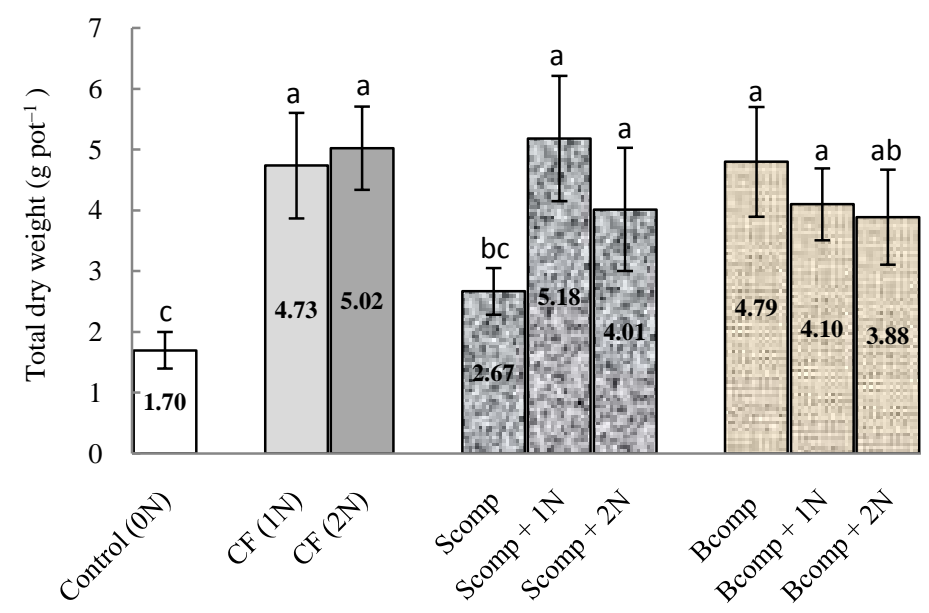

Figure 1. Total dry weight (means and standard errors) as influenced by different fertilizer treatments. The same lower case letters on SD bars are not least significantly different at 0.01 level.

Table 3. Total plant nitrogen uptake and plant $\mathrm{N}$ derived from compost $\left(\mathrm{N}_{\mathrm{dfComp}}\right)$, chemical fertilizer $\left(\mathrm{N}_{\mathrm{dfCF}}\right)$, and soil ( $\left.\mathrm{N}_{\mathrm{dfS}}\right)$ as influenced by different fertilizer treatments.

\begin{tabular}{|c|c|c|c|c|c|c|c|}
\hline \multirow{3}{*}{ Treatments } & \multicolumn{2}{|c|}{ Compost source } & \multicolumn{2}{|c|}{ CF source } & \multirow{2}{*}{$\begin{array}{c}\text { Soil } \\
\text { NdfS }\end{array}$} & \multirow{2}{*}{$\begin{array}{c}\text { Total } \\
\mathrm{N} \text { uptake }\end{array}$} & \multirow{2}{*}{$\begin{array}{l}\mathrm{N} \text { uptake } \\
\text { efficiency }\end{array}$} \\
\hline & $\mathrm{N}_{\text {dfComp }}$ & $\%$ of added $\mathrm{N}$ & $\mathrm{N}_{\mathrm{dfCF}}$ & \% of added $\mathrm{N}$ & & & \\
\hline & $\mathrm{mg} \cdot$ pot $^{-1}$ & & $\mathrm{mg} \cdot \operatorname{pot}^{-1}$ & & $\mathrm{mg} \cdot \operatorname{pot}^{-1}$ & $\mathrm{mg} \cdot \operatorname{pot}^{-1}$ & $\%$ \\
\hline Control (0N) & - & - & - & - & 18.27 & $18.27 \mathrm{~d}$ & - \\
\hline $\mathrm{CF}(1 \mathrm{~N})$ & - & - & $75.48 \mathrm{~b}$ & 58 & 27.83 & $103.31 \mathrm{~b}$ & $65.4 \mathrm{a}$ \\
\hline CF $(2 N)$ & - & - & 111.09 a & 43 & 26.67 & 137.76 a & $46.0 \mathrm{~b}$ \\
\hline Scomp & $36.97 \mathrm{~b}^{\dagger}$ & 28 & - & - & 18.27 & $55.24 \mathrm{c}$ & $28.2 \mathrm{c}$ \\
\hline Scomp + 1N & $37.66 \mathrm{~b}$ & 29 & 72.20 bc & 56 & 27.83 & 137.69 a & $45.9 \mathrm{~b}$ \\
\hline Scomp $+2 \mathrm{~N}$ & $4.61 \mathrm{c}$ & 4 & 59.91 bc & 23 & 26.67 & $91.19 \mathrm{~b}$ & 18.7 c \\
\hline Bcomp & 80.56 a & 62 & - & - & 18.27 & $98.83 \mathrm{~b}$ & $62.0 \mathrm{a}$ \\
\hline Bcomp + 1N & $24.60 \mathrm{~b}$ & 19 & $39.03 \mathrm{~d}$ & 30 & 27.83 & $91.46 \mathrm{~b}$ & $28.4 \mathrm{c}$ \\
\hline $\mathrm{Bcomp}+2 \mathrm{~N}$ & $24.46 \mathrm{~b}$ & 19 & 57.39 c & 22 & 26.67 & 108.52 b & 23.2 c \\
\hline $\mathrm{P}>\mathrm{F}$ & ** & & ** & & & ${ }^{* *}$ & $* *$ \\
\hline LSD & 18.89 & & 17.60 & & & 24.96 & 13.28 \\
\hline
\end{tabular}

Means in a column followed by the same lower case are not least significantly different at the $0.01^{* *}$ level.

of Scomp $+1 \mathrm{~N}$ treatment. When combining Bcomp with $1 \mathrm{~N}$ and $2 \mathrm{~N}$, the percentage of added compost-N was both decreased from $62 \%$ to $19 \%$. For Scomp, those were $29 \%$ and $4 \%$, respectively. The percentages of added compost- $\mathrm{N}$ between Scomp and Scomp $+1 \mathrm{~N}$ treatments were similar, which were equal to a half of Bcomp alone (62\%) (Table 3). The $\mathrm{N}_{\mathrm{dfCF}}$ values were useful to compare difference between $\mathrm{CF}$ alone and blend treatments. Similarly, combining CF with either Scomp or Bcomp caused to significant decrease $(P<0.01)$ of $\mathrm{N}_{\mathrm{dfCF}}$ compared to CF alone, with the exception of Scomp $+1 \mathrm{~N}$. Consequently, the percentages of added chemical fertilizer-N were also lowered from $43 \%$ - 58\% to $23 \%$ - 56\% and 22\% - 30\% for Scomp and Bcomp blended treatments, respectively.

$\mathrm{N}_{\text {dfs }}$ of CF fertilized treatments were observed to be higher than CF unfertilized treatments. These values were not used for statistical analysis within because data were simulated from control and CF alone treatments. 
Total nitrogen uptake (TNU) was generally similar to total dry weight data (Table 3 and Figure 1). The only differences were that $\mathrm{N}$ uptake from Scomp $+1 \mathrm{~N}$ was significantly higher $(P<0.01)$ than Scomp $+2 \mathrm{~N}$, Scomp $+2 \mathrm{~N}$ was higher than Scomp, and Scomp was higher than control treatment. The results also show that combining composts with CF did not increase the TNU and NUE compare to CF alone. With the exception of Scomp + $1 \mathrm{~N}$ treatment, TNU was remarkably enhanced by $137.69 \mathrm{mg} \cdot \mathrm{N} \cdot \operatorname{pot}^{-1}$. Interestingly, TNU and NUE of Bcomp (98.83 mg.pot ${ }^{-1}$ and $\left.62.0 \%\right)$ were similar to CF (1N) (103.31 mg.pot ${ }^{-1}$ and 65.4\%), but significantly higher $(P<$ 0.01) than Scomp alone (55.24 $\mathrm{mg} \cdot$ pot $^{-1}$ and $28.2 \%$, respectively).

The relationships between nitrogen uptake and total dry weight are illustrated in Figures 2-5. The results of the correlation analysis indicate that total biomass was closely associated with TNU $\left(R^{2}=0.900\right)$, while less closely associated with $N_{\text {dfCF }}\left(R^{2}=0.530\right)$, poorly associated with $N_{\text {dfs }}$ and $N_{\text {dfComp }}\left(R^{2}=0.396\right.$ and $R^{2}=0.111$, respectively).

\subsection{Incubation Study}

(1) Soil Inorganic Nitrogen Contents and Recovery of Applied Nitrogen

Changes in the ammonium $\left(\mathrm{NH}_{4}-\mathrm{N}\right)$ and nitrate nitrogen $\left(\mathrm{NO}_{3}-\mathrm{N}\right)$ contents during incubation are shown in Table 4 and Figure 6. There was a considerable decrease of $\mathrm{NH}_{4}-\mathrm{N}$ from $200-400 \mathrm{mg} \cdot \mathrm{kg}^{-1}$ on day 0 to 15.1 $95.1 \mathrm{mg} \cdot \mathrm{kg}^{-1}$ on day 10 . At the same time, there is a remarkable increase of $\mathrm{NO}_{3}-\mathrm{N}$ from day 5 . After 10 days of incubation, total inorganic nitrogen, $\mathrm{NH}_{4}-\mathrm{N}$, and $\mathrm{NO}_{3}-\mathrm{N}$ contents were significantly higher at $2 \mathrm{~N}$ than $1 \mathrm{~N}$ may due to different initial contents. The increase of temperature from $25^{\circ} \mathrm{C}$ to $35^{\circ} \mathrm{C}$ does not seem to affect $\mathrm{NH}_{4}-\mathrm{N}$ content, but significantly increased $(P<0.01) \mathrm{NO}_{3}-\mathrm{N}$ as well as total inorganic $\mathrm{N}$ content (Table 4).

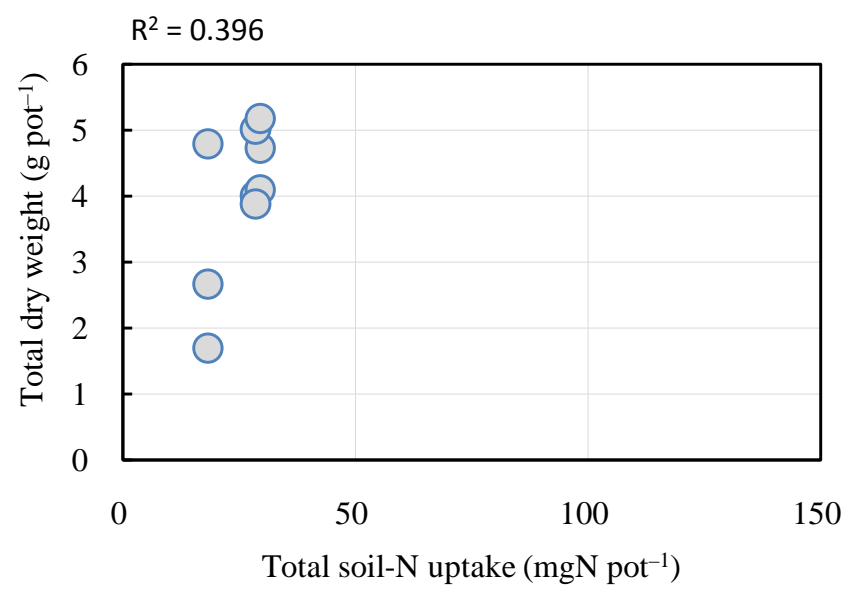

Figure 2. Relationship between total dry weight and total soil-N uptake.

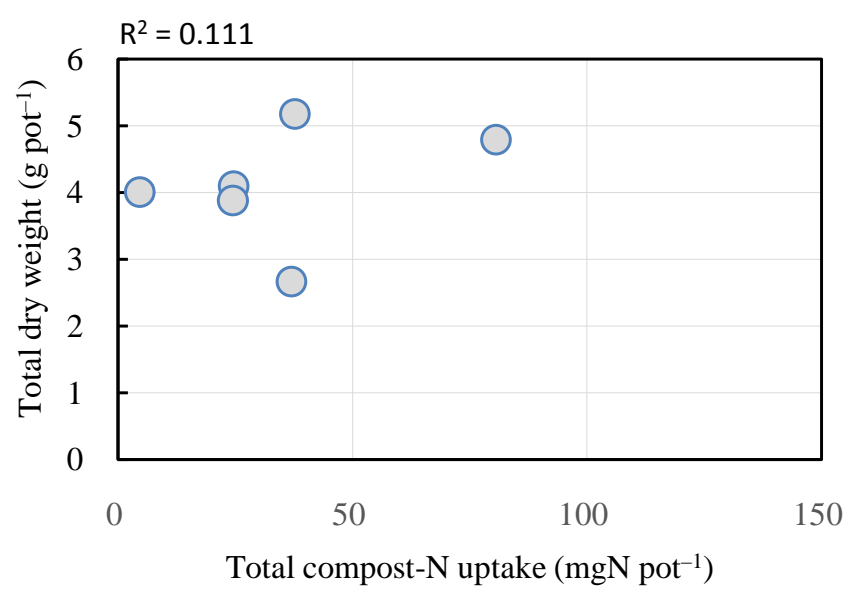

Figure 3. Relationship between total dry weight and total compost-Nuptake. 


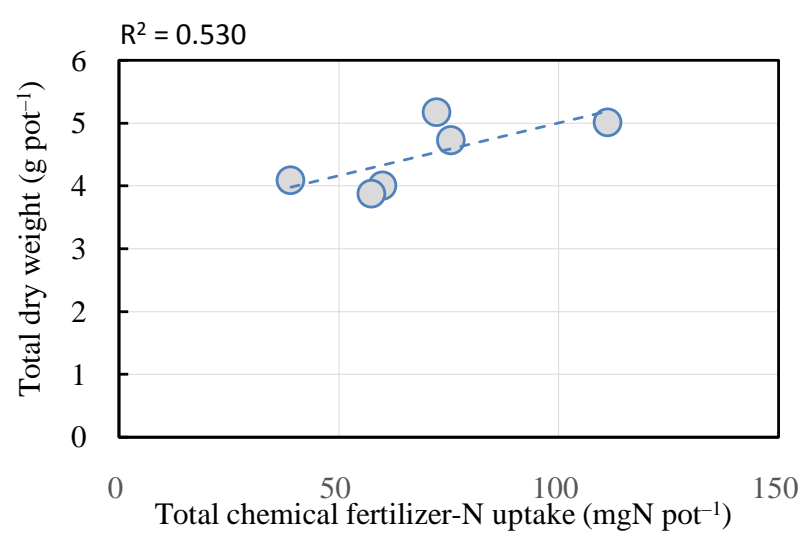

Figure 4. Relationship between total dry weight and total chemical fertilizer-N uptake.

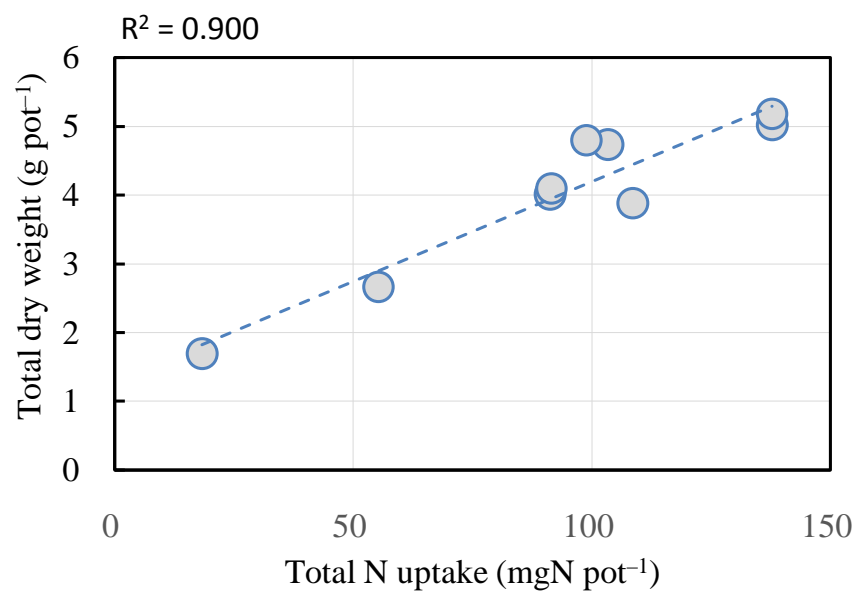

Figure 5. Relationship between total dry weight and total N uptake (TNU).

$\mathbf{\square} \%$ Recovered in $\mathrm{NO}_{3}-\mathrm{N}$

$\square \%$ Recovered in $\mathrm{NH}_{4}-\mathrm{N}$

$\square \%$ Recovered in Organic N

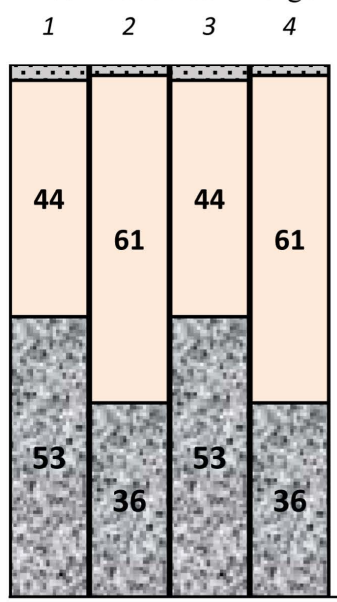

0

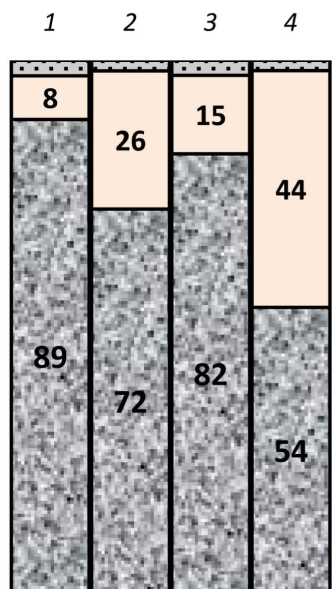

2

\begin{tabular}{ccc} 
1. & $25^{\circ} \mathrm{C}$ & Scomp $+1 \mathrm{~N}$ \\
2. & & Scomp $+2 \mathrm{~N}$ \\
\hline 3. & $35^{\circ} \mathrm{C}$ & Scomp $+1 \mathrm{~N}$ \\
4. & & Scomp $+2 \mathrm{~N}$ \\
\hline
\end{tabular}

13

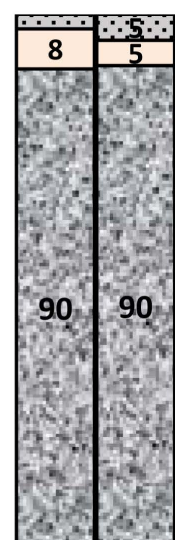

5

Period of Incubation Days

Figure 6. Recovery of nitrogen in organic and inorganic fractions at different incubation periods. 
Table 4. Soil inorganic nitrogen fractions as influenced by temperature and additional $\mathrm{N}$ rates.

\begin{tabular}{|c|c|c|c|c|c|c|}
\hline \multirow{2}{*}{$\mathrm{N}$ fractions } & \multirow{2}{*}{ Temp } & \multirow{2}{*}{ Treatments } & \multicolumn{4}{|c|}{ Period of incubation (day) } \\
\hline & & & 0 & 2 & 5 & 10 \\
\hline & & & \multicolumn{4}{|c|}{ 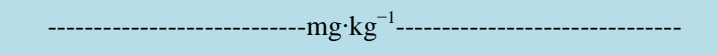 } \\
\hline \multirow{4}{*}{$\mathrm{NH}_{4}-\mathrm{N}$} & \multirow{2}{*}{$25^{\circ} \mathrm{C}$} & Scomp $+1 \mathrm{~N}$ & 200.0 & $36.9 c^{\dagger}$ & $34.0 \mathrm{c}$ & 17.3 \\
\hline & & Scomp $+2 \mathrm{~N}$ & 400.0 & $168.8 \mathrm{~b}$ & $115.2 \mathrm{~b}$ & 88.2 \\
\hline & \multirow{2}{*}{$35^{\circ} \mathrm{C}$} & Scomp $+1 \mathrm{~N}$ & 200.0 & $66.5 \mathrm{c}$ & $21.4 \mathrm{c}$ & 15.1 \\
\hline & & Scomp $+2 \mathrm{~N}$ & 400.0 & 289.3 a & $168.3 \mathrm{a}$ & 95.1 \\
\hline \multirow{3}{*}{$\begin{array}{l}\hat{L} \\
\hat{2} \\
\hat{2}\end{array}$} & \multicolumn{2}{|c|}{ Тетр } & & ** & * & ns \\
\hline & \multicolumn{2}{|c|}{$N$ rate } & & ** & $* *$ & $* *$ \\
\hline & \multicolumn{2}{|c|}{ Temp $\times N$ rate } & & $* *$ & ** & ns \\
\hline \multirow{4}{*}{$\mathrm{NO}_{3}-\mathrm{N}$} & \multirow{2}{*}{$25^{\circ} \mathrm{C}$} & Scomp $+1 \mathrm{~N}$ & 13.5 & 13.1 & 12.3 & 26.2 \\
\hline & & Scomp $+2 \mathrm{~N}$ & 13.5 & 12.9 & 16.2 & 35.9 \\
\hline & \multirow{2}{*}{$35^{\circ} \mathrm{C}$} & Scomp $+1 \mathrm{~N}$ & 13.5 & 12.7 & 22.0 & 41.7 \\
\hline & & Scomp $+2 \mathrm{~N}$ & 13.5 & 12.7 & 25.0 & 59.1 \\
\hline \multirow{3}{*}{$\begin{array}{l}\hat{L} \\
\hat{\alpha}\end{array}$} & \multicolumn{2}{|c|}{ Тетр } & & ns & ** & ** \\
\hline & \multicolumn{2}{|c|}{$N$ rate } & & ns & ns & ** \\
\hline & \multicolumn{2}{|c|}{ Temp $\times N$ rate } & & ns & ns & ns \\
\hline \multirow{4}{*}{$\Sigma \mathrm{NH}_{4}+\mathrm{NO}_{3}$} & \multirow{2}{*}{$25^{\circ} \mathrm{C}$} & Scomp $+1 \mathrm{~N}$ & 213.6 & $50.0 \mathrm{c}$ & $46.2 \mathrm{c}$ & 43.5 \\
\hline & & Scomp $+2 \mathrm{~N}$ & 413.6 & $181.7 \mathrm{~b}$ & $131.4 \mathrm{~b}$ & 124.0 \\
\hline & \multirow{2}{*}{$35^{\circ} \mathrm{C}$} & Scomp $+1 \mathrm{~N}$ & 213.6 & $79.2 \mathrm{c}$ & $43.4 \mathrm{c}$ & 56.8 \\
\hline & & Scomp $+2 \mathrm{~N}$ & 413.6 & 301.9 a & 193.3 a & 154.2 \\
\hline \multirow{3}{*}{$\begin{array}{l}\hat{1} \\
\hat{\alpha} \\
\hat{a}\end{array}$} & \multicolumn{2}{|c|}{ Temp } & & ** & $* *$ & ** \\
\hline & \multicolumn{2}{|c|}{$N$ rate } & & ** & ** & $* *$ \\
\hline & \multicolumn{2}{|c|}{ Temp $\times N$ rate } & & ** & ** & ns \\
\hline
\end{tabular}

${ }^{\dagger}$ Means in a column and same $\mathrm{N}$ fraction followed by the same lower are not least significantly different at the $0.01^{* *}$ and $0.05^{*}$ levels. Ns $=$ not significantly different.

Recovery of applied nitrogen in organic- $\mathrm{N}, \mathrm{NH}_{4}-\mathrm{N}$, and $\mathrm{NO}_{3}-\mathrm{N}$ are given in Figure 6. The results indicate that the recovery of applied nitrogen in organic form significantly increased within 10 days of incubation, while those in $\mathrm{NH}_{4}-\mathrm{N}$ sharply decreased from day 2 especially at $25^{\circ} \mathrm{C}$. At the same rate of added $\mathrm{N}$, effects of temperature on recovery of organic $\mathrm{N}$ or $\mathrm{NH}_{4}-\mathrm{N}$ behave in a similar manner. At the same temperature, the recovery of applied nitrogen in the organic $\mathrm{N}$ was higher at $1 \mathrm{~N}$ than $2 \mathrm{~N}$, whereas those of $\mathrm{NH}_{4}-\mathrm{N}$ in $2 \mathrm{~N}$ were higher. After 10 days of incubation, about $6 \%$ - 9\% of total applied $\mathrm{N}$ were recovered in $\mathrm{NO}_{3}-\mathrm{N}$ form (Figure 6).

(2) Net Mineralization and Gross Total N Transformation

Table 5 summarizes soil nitrogen transformation rates between organic and inorganic pools. Some ${ }^{15} \mathrm{~N}$ values of Scomp $+2 \mathrm{~N}$ treatment on day 5 could not be measured because of failure of isotopic analysis system. Net mineralization rates $\left(\mathrm{N}_{m i}\right)$ were previously calculated by the difference of total inorganic nitrogen. The results show that temperature and added $\mathrm{N}$ rates had significant effects $(P<0.05$ and $P<0.01$, respectively) on net mineralization rates during the incubation. The results show that $\mathrm{N}_{m i}$ rates in all treatments had large negative values, suggesting a net immobilization in soil (since immobilization > mineralization). With the exception of Scomp $+1 \mathrm{~N}$ at $35^{\circ} \mathrm{C}$ during $5-10$ days of incubation, $\mathrm{N}_{m i}$ shows a small positive value $\left(+2.68 \mathrm{mg} \cdot \mathrm{kg}^{-1} \cdot \mathrm{soil}^{-} \cdot \mathrm{day}^{-1}\right)$.

Although $\mathrm{N}_{m i}$ rates are useful to evaluate the size of inorganic nitrogen in soil, they do not provide further in- 
Table 5. Soil nitrogen transformation rates calculated from ${ }^{15} \mathrm{~N}$ pool dilution experiment.

\begin{tabular}{|c|c|c|c|c|c|}
\hline \multirow{2}{*}{$\begin{array}{l}\text { Period of } \\
\text { incubation } \\
\text { days }\end{array}$} & \multirow{2}{*}{ Temp } & \multirow{2}{*}{ Treatments } & \multicolumn{3}{|c|}{$\mathrm{N}$ transformation $\left(\mathrm{mg} \cdot \mathrm{kg}^{-1} \cdot\right.$ soil $\left.\cdot \mathrm{day}^{-1}\right)$} \\
\hline & & & Gross mineralization $\left(\mathrm{G}_{m i}\right)$ & Gross immobilization $\left(\mathrm{G}_{\text {im }}\right)$ & Net mineralization $\left(\mathrm{N}_{m i}\right)$ \\
\hline \multirow{4}{*}{$\mathrm{t}=0-2$} & \multirow{2}{*}{$25^{\circ} \mathrm{C}$} & Scomp $+1 \mathrm{~N}$ & 1.90 & 83.70 & -81.78 \\
\hline & & Scomp $+2 \mathrm{~N}$ & 2.66 & 118.59 & -115.93 \\
\hline & \multirow{2}{*}{$35^{\circ} \mathrm{C}$} & Scomp $+1 \mathrm{~N}$ & 1.65 & 68.90 & -67.20 \\
\hline & & Scomp $+2 \mathrm{~N}$ & 1.06 & 56.89 & -55.83 \\
\hline \multirow{2}{*}{$t=2-5$} & $25^{\circ} \mathrm{C}$ & Scomp $+1 \mathrm{~N}$ & 0.23 & 1.50 & -1.27 \\
\hline & $35^{\circ} \mathrm{C}$ & Scomp $+1 \mathrm{~N}$ & 1.97 & 13.90 & -11.93 \\
\hline \multirow{2}{*}{$t=5-10$} & $25^{\circ} \mathrm{C}$ & Scomp $+1 \mathrm{~N}$ & 0.52 & 1.07 & -0.55 \\
\hline & $35^{\circ} \mathrm{C}$ & Scomp $+1 \mathrm{~N}$ & 2.95 & 0.24 & +2.68 \\
\hline \multirow{6}{*}{$t=0-10$} & \multirow{2}{*}{$25^{\circ} \mathrm{C}$} & Scomp $+1 \mathrm{~N}$ & 0.42 & 17.43 & -17.01 \\
\hline & & Scomp $+2 \mathrm{~N}$ & 0.66 & 29.62 & -28.96 \\
\hline & Mean & & 0.54 & $23.50 \mathrm{~A}$ & $-22.99 B$ \\
\hline & \multirow{2}{*}{$35^{\circ} \mathrm{C}$} & Scomp $+1 \mathrm{~N}$ & 0.40 & 16.08 & -15.68 \\
\hline & & Scomp $+2 \mathrm{~N}$ & 0.55 & 26.50 & -25.94 \\
\hline & Mean & & 0.48 & $21.30 \mathrm{~B}$ & $-20.81 \mathrm{~A}$ \\
\hline \multirow{3}{*}{$\begin{array}{l}\hat{L} \\
\hat{2} \\
\hat{\alpha}\end{array}$} & & Гетр & ns & * & * \\
\hline & & I rate & ** & ** & ** \\
\hline & \multicolumn{2}{|c|}{ Temp $\times N$ rate } & ns & ns & ns \\
\hline
\end{tabular}

${ }^{\dagger}$ Means in a column followed by the same capital letters are not least significantly different at the $0.01^{* *}$ and 0.05 level. Ns $=$ not significantly different.

formation regarding flow of nitrogen into or out of each $N$ pool. Therefore, the gross total $N$ mineralization $\left(\mathrm{G}_{m i}\right)$ and gross total $\mathrm{N}$ immobilization $\left(\mathrm{G}_{i m}\right)$ are more suitable to understand the interaction between organic and inorganic sources. Interestingly, the data show that $\mathrm{G}_{i m}$ rates were observed to be dominant and much higher than $\mathrm{G}_{m i}$ at almost intervals of incubation. $\mathrm{G}_{i m}$ was also affected by the change of temperature, which was significantly higher $(P<0.05)$ at $25^{\circ} \mathrm{C}$ than $35^{\circ} \mathrm{C}$. At the same temperature, Scomp $+2 \mathrm{~N}$ gave larger $\mathrm{G}_{i m}$ than did Scomp $+1 \mathrm{~N}$. In contrast, $\mathrm{G}_{m i}$ rates were not affected by temperature, while those of Scomp $+2 \mathrm{~N}$ were significantly higher $(P<0.01)$ than Scomp $+1 \mathrm{~N}$.

After 10 days of incubation, the results show that $16.08-29.62 \mathrm{mg} \mathrm{N} \cdot \mathrm{kg}^{-1} \cdot \mathrm{day}^{-1}$ soil from inorganic-N were immobilized into organic pools, while only $0.40-0.66 \mathrm{mg} \mathrm{N} \cdot \mathrm{kg}^{-1} \cdot \mathrm{day}^{-1}$ soil from organic- $\mathrm{N}$ were mineralized to inorganic pools (Table 5).

\section{Discussion}

Biosolids compost, which was produced from by-product of waste water treatment, had more nitrogen and lower $\mathrm{C}: \mathrm{N}$ ratio (6.6) than did solids compost (10.8). The increase of biomass and total nitrogen uptake may due to higher mineral $\mathrm{N}$ value released from decomposition of organic matter in Bcomp than Scomp. In addition, the possible proportion of nitrogen recalcitrant compounds in solids waste compost could make it less efficient to supply available nitrogen for ryegrass.

Data from combination treatments in current study show that neither total biomass nor nitrogen uptake efficiency was significantly increased in the presence of compost compared to chemical fertilizer alone. Interestingly, only Scomp complemented with chemical $\mathrm{N}$ fertilizer increased yield, $\mathrm{N}$ uptake, and $\mathrm{N}$ uptake efficiency over those of Scomp alone. However, ${ }^{15} \mathrm{~N}$ data accumulated in plant and correlation analysis presented herein 
indicate that the incremental yield of Scomp $+1 \mathrm{~N}$ was attributed to the contribution of added $\mathrm{N}$ from chemical fertilizer rather than from mineralized compost-N, which was contrary to our expectation.

The higher $\mathrm{N}_{\mathrm{dfs}}$ from fertilized treatments than unfertilized treatment was due to pool substitution between ${ }^{14} \mathrm{~N}$ and ${ }^{15} \mathrm{~N}$ in the soil [16]. Total plant nitrogen uptake derived from composts or derived from chemical fertilizer was decreased through combination treatments, suggesting that either competition of $\mathrm{N}$ for plant uptake [17] or excess salt concentrations in amended soil could inhibit the plant growth.

The net mineralization could occur where compost had C:N ratio lower than 20:1 and $\mathrm{N}$ concentration greater than 1.6\% [18]. However, Hart et al. [19] noticed that compost nitrogen could also be immobilized for a short time despite a low C:N ratio $(<12)$ due to $\mathrm{N}$ concentration lower than $1.6 \%$. In this study, such large numbers of gross immobilization rates and small gross mineralization rates detected at the early stage after blending may be related to term "lag period", in which the amount of microbial biomass $\mathrm{N}$ increased remarkably, as reported by Masakazu and Nozawa [20]. The pattern of net immobilization herein for 10 days incubation study was consistent with those of Handas and Portnoy [21]; Yevdokimov et al. [22], who indicated that the portion of added inorganic nitrogen was immobilized by soil microbial community. In spite of a temporary reduction of mineral N, retention of nitrogen in the compost amended soil could reduce environmental risk of $\mathrm{N}$ losses from agriculture land.

A sharp increase of organic ${ }^{15} \mathrm{~N}$ atom \% after combining compost with ${ }^{15} \mathrm{~N}$ labeled ammonium sulfate (data not shown) indicates that there was a considerable input of ${ }^{15} \mathrm{~N}$ from inorganic $\mathrm{N}$ pools. These were properly corresponding to the significant decrease of $\mathrm{NH}_{4}-\mathrm{N}$ content of the inorganic $\mathrm{N}$ pools, as observed by Compton [23]. The addition net cumulative nitrate $\mathrm{NO}_{3}-\mathrm{N}$ released after 10 days of incubation, suggesting that microorganisms (nitrifiers) could be activated by consumption of $\mathrm{NH}_{4}-\mathrm{N}$ and producing $\mathrm{NO}_{3}-\mathrm{N}$. The effects of temperature and added $\mathrm{N}$ rates from chemical fertilizer on gross total $\mathrm{N}$ transformation were also observed. These data could provide useful information about nitrogen cycling between organic and inorganic $\mathrm{N}$ sources in soil. The slight decrease of immobilization rates as affected by higher temperature in this study could attribute for a possible immobilization by microbial biomass rather than abiotic physical fixation. Joergensen et al. [24] indicated that increasing incubation temperature from $25^{\circ} \mathrm{C}$ to $35^{\circ} \mathrm{C}$ resulted in enhanced substrate decomposition due to increased specific death rates of microorganisms. Although some results were observed from the short-term incubation study, these data could not be enough to explain the interactions that take place at Scomp $+1 \mathrm{~N}$ treatment to be account for its incremental yield.

\section{Conclusions}

Biosolids compost by itself could provide available nitrogen for plant requirement as a soil fertilizer. The combination of composts and chemical $\mathrm{N}$ fertilizer did not significantly increase ryegrass yield and $\mathrm{N}$ uptake efficiency compared to CF alone. However, blend of solids compost and CF (1N) could improve yield, N uptake and $\mathrm{N}$ uptake efficiency over those of compost alone. For this case, the ${ }^{15} \mathrm{~N}$ data herein indicate that $29 \%$ of added $\mathrm{N}$ derived from solids compost, while $56 \%$ of added $\mathrm{N}$ derived from $\mathrm{CF}$.

Under the conditions of this study, the soil $\mathrm{N}$ transformation was stimulated after combining by increasing immobilization rather than mineralization at the early stage, suggesting a remarkable retention of added $\mathrm{N}$ in solids compost amended soil.

Combining compost containing low nitrogen percentage with chemical $\mathrm{N}$ fertilizer could be considered to utilize solids compost more effectively for recycling of organic waste in Vietnam.

\section{Acknowledgements}

The authors wish to express our appreciation to Okayama-Hue International Master's Program. Our gratitude also goes to Assoc. Prof. Carl R. Crozier and two anonymous reviewers for their valuable comments on the manuscript.

\section{References}

[1] Iglesias, E. and Alvarez, C.E. (1993) Apparent Availability of Nitrogen in Composted Municipal Refuse. Biology and Fertility of Soils, 16, 313-318. http://dx.doi.org/10.1007/BF00369312

[2] Rodrigo, S.C., White, R.E. and Weatherley, A.J. (2005) Biosolids Effectiveness to Yield Ryegrass Based on Their Ni- 
trogen Content. Scientia Agricola, 62, 274-280. http://dx.doi.org/10.1590/S0103-90162005000300011

[3] Giusquiani, P.L., Pagliai, M., Gigliotti, G., Businelli, D. and Benetti, A. (1995) Urban Waste Compost: Effects on Physical, Chemical, and Biochemical Soil Properties. Journal of Environmental Quality, 24, 175-182. http://dx.doi.org/10.2134/jeq1995.00472425002400010024x

[4] Scherer, H.W., Metker, D.J. and Welp, G. (2011) Effect of Long-Term Organic Admendments on Chemical and Microbial Properties of Luvisol. Plant, Soil and Environment, 57, 513-518. http://www.agriculturejournals.cz/publicFiles/50060.pdf

[5] Hoang, N.X. and Viet, L.H. (2011) Solid Waste Management in Mekong Delta. Journal of Vietnamese Environment, 1, 27-33.

[6] Ashgar, M.I., Zahir, A.A., Khalid, M. and Arshad, M. (2006) Response of Radish to Integrated Use of Nitrogen Fertilizer and Recycled Organic Waste. Pakistan Journal of Botany, 38, 691-700.

[7] Esawy, M., Nasser, A., Paul, R., Nouraya, A. and Lamyaa, A. (2009) Effects of Different Organic and Inorganic Fertilizers on Cucumber Yield and Some Soil Properties. World Journal of Agricultural Sciences, 5, 408-414.

[8] Wolf, D.C., Legg, J.O. and Boutton, T.W. (1994) Isotopic Methods for the Study of Soil Organic Matter Dynamics. In: Weaver, R.W., Angle, S., Bottomly, P., Bezdicek, D., Smith, S., Tabatabai, A. and Wollum, A., Eds., Methods of Soil Analysis. Part 2. Microbiological and Biochemical Properties, SSSA, Madison, 865-906.

[9] Hauck, R., Meisinger, J.J. and Mulvaney, C.S. (1994) Practical Considerations in the Use of Nitrogen Tracers in Agricultural and Environmental Research. In: Weaver, R.W., Angle, S., Bottomly, P., Bezdicek, D., Smith, S., Tabatabai, A. and Wollum, A., Eds., Methods of Soil Analysis. Part 2. Microbiological and Biochemical Properties, SSSA, Madison, 907-943.

[10] Murphy, D.V., Recous, S., Stockdale, E.A., Fillery, I.R.P., Jensen, L.S., Hatch, D.J. and Goulding, K.W.T. (2003) Gross Nitrogen Fluxes in Soil: Theory, Measurement and Application of $15 \mathrm{~N}$ Pool Dilution Techniques. Advance in Agronomy, 79, 69-118. http://dx.doi.org/10.1016/S0065-2113(02)79002-0

[11] Binh, N.T., Quynh, H.T., Oshiro, S. and Shima, K. (2015) Evaluation of Sewage Sludge Compost Quality through Maturity Index and Biomass Yield of Italian Ryegrass (Lolium multiforum L.). Journal of Science, Technology and Development, Manuscript Submitted for Publication (Copy on File with Author).

[12] Doane, T.A. and Horwath, W.R. (2003) Spectrophotometric Determination of Nitrate with a Single Reagent. Analytical Letters, 36, 2713-2722. http://dx.doi.org/10.1081/AL-120024647

[13] Hauck, R.D. and Bremner, J.M. (1976) Use of Tracers for Soil and Fertilizer Nitrogen Research. Advances in Agronomy, 28, 219-266. http://dx.doi.org/10.1016/S0065-2113(08)60556-8

[14] Westerman, R.L. and Kurtz, L.T. (1974) Isotopic and Nonisotopic Estimation of Fertilizer Nitrogen Uptake by Sudangrass in Field Experiment. Soil Science Society of America Journal, 38, 107-109. http://dx.doi.org/10.2136/sssaj1974.03615995003800010033x

[15] Onofri, A. and Pannacci, E. (2014) Spreadsheet Tools for Biometry Classes in Crop Science Programmes. Communications in Biometry and Crop Science, 9, 43-53.

[16] Hart, P.B.S., Rayner, J.H. and Jenkinson, D.S. (1986) Influence of Pool Substitution on the Interpretation of Fertilizer Experiments with ${ }^{15}$ N. Journal of Soil Science, 37, 389-403. http://dx.doi.org/10.1111/j.1365-2389.1986.tb00372.x

[17] Choi, W.S., Jin, S.A., Lee, S.M., Ro, H.M. and Yoo, S.H. (2001) Corn Uptake and Microbial Immobilization of ${ }^{15}$ NLabeled Urea-N in Soil as Affected by Composted Pig Manure. Plant and Soil, 235, 1-9. http://dx.doi.org/10.1023/A:1011896912888

[18] Ozorez-Hampton, M.P. and Obreza, T.A. (2001) Evaluation of in Situ N Mineralization of Composted Organic Wastes Applied to Sandy Soil. Proceedings of the Florida State Horticultural Society, 114, 342-346.

[19] Hartz, T.K., Costa, F.J. and Schrader, W.L. (1996) Suitability of Composted Green Waste for Horticulture Uses. HortScience, 31, 961-964.

[20] Masakazu, A. and Nozawa, T. (2012) Microbial Biomass Nitrogen and Mineralization Immobilization Processes of Nitrogen in Soils Incubated with Various Organic Materials. Soil Science and Plant Nutrition, 39, 23-32.

[21] Hadas, A. and Portnoy, R. (1994) Nitrogen and Carbon Mineralization Rates of Composted Manures Incubated in Soil. Journal of Environmental Quality, 23, 1184-1189. http://dx.doi.org/10.2134/jeq1994.00472425002300060008x

[22] Yevdokimov, I.V., Gattinger, A., Buegger, F., Schloter, M. and Munch, J.C. (2011) Changes in Structure and Activity of a Soil Microbial Community Caused by Inorganic Nitrogen Fertilization. Microbiology, 81, 743-749. http://dx.doi.org/10.1134/S0026261712060045

[23] Compton, J.E. and Boone, R. (2002) Soil Nitrogen Transformations and the Role of Light Fraction Organic Matter in Forest Soils. Soil Biology and Biochemistry, 34, 933-943. http://dx.doi.org/10.1016/S0038-0717(02)00025-1

[24] Joergensen, R.G., Brookes, P.C. and Jenkinson, D.S. (1990) Survival of the Soil Microbial Biomass at Elevated Temperatures. Soil Biology Biochemistry, 22, 1129-1136. http://dx.doi.org/10.1016/0038-0717(90)90039-3 